\title{
Perspektywa porównawcza w dydaktyce języka ojczystego
}

\author{
Comparative perspective \\ in didactics of the mother tongue
}

\begin{abstract}
The author of a critical review of the monograph entitled Język ojczysty w edukacji szkolnej w Polsce, Czechach i na Stowacji [The mother tongue in school education in Poland, the Czech Republic, and Slovakia] presents the possibilities of conducting comparative research in the field of mother-tongue teaching. Until now, researchers of this sub-discipline have rarely used the achievements used by linguists from abroad. The situation - as the monograph analyzed by the author shows - is slowly changing. The studies presented in the reviewed book concern didactic aspects of various levels of language. They are similar in a functional approach to teaching the mother tongue. The author of the review points out that such profiled research on language education in one country may raise awareness of language education in neighboring countries.
\end{abstract}

Keyword s: mother tongue didactics, comparative didactics L1

\section{Wprowadzenie}

W każdym systemie oświaty za jedno z ważniejszych zadań szkoły uznaje się kształcenie umiejętności posługiwania się językiem ojczystym, nadaje się przy tym temu kształceniu szczególną, wyróżnioną pozycję w podstawie programowej kształcenia ogólnego. Zmiany w planach ramowych nauczania języka ojczystego wywołują zazwyczaj burzliwe dyskusje (jak choćby uwagi i kontrowersje wywołane zmianami w podstawie programowej języka polskie- 
go wprowadzone w Polsce w 2017 roku), zwykle jednak zamykają się w granicach krajowego systemu oświaty odnoszonego do języka rodzimego. Bardzo rzadko badacze spoglądają, ,jak to robią sąsiedzi”, próbują skorzystać z ich doświadczeń. Tymczasem okazuje się, że badania porównawcze w tym zakresie są możliwe - postulaty dotyczące dydaktyki języków ojczystych sformułowano już jakiś czas temu. Jak napisał Marek Pieniążek,

w programowaniu edukacji języków ojczystych obecnie bardzo potrzebna jest transnarodowa perspektywa, która uwzględni wielość światowych procesów, wywołujących trudności z zachowaniem trwałości i funkcjonalności języków narodowych w krajach Europy Środkowej'.

Komparatystyczne spojrzenie może wskazać na rozwiązywane problemy z szerszej niż tylko narodowa czy systemowo-teoretyczna perspektywa. Taką perspektywę zyskuje odbiorca monografii pt. Język ojczysty w edukacji szkolnej w Polsce, Czechach i na Stowacji².

\section{Koncepcja, autorzy i tematy}

Monografia stanowi unikalne opracowanie poświęcone zagadnieniom dydaktycznej komparatystyki języków ojczystych, odpowiadające na potrzeby dydaktyki J1 z obszaru czesko-polsko-słowackiego.

Pojęcie komparatystyki, stosowane przede wszystkim w badaniach literaturoznawczych, kulturoznawczych czy językoznawczych, odsyła do czynności porównywania, rezultatu i stosunku porównawczego. Wchodzimy zatem w krąg badań porównawczych ze świadomością, że wyróżniały się one, zwłaszcza $\mathrm{w}$ ponowoczesnej komparatystyce ostatnich dekad, cechą interdyscyplinarności. Dydaktyka języka rodzimego w założeniu charakteryzuje się integralnością rozmaitych dyscyplin, opracowania komparatystyczne dydaktyk języków ojczystych mają zatem u podstaw charakter interdyscyplinarny, choć pozostają projektami metanauki czy metateorii („teorii teorii”’3), sięgającymi do szerokiego kontekstu. Komparatystyka w rozumieniu redaktorów tomu nie ogranicza się do refleksji o porównywaniu i porównaniach dokonywanych

${ }^{1}$ M. Pieniążek: Język ojczysty jako „software”. Polityka językowa i technologia. „LIK: časopis za literaturu i kulturu" 2017, vol. 3, no. 4, s. 158. https://doi.org/10.18485/ai_lik.2017.3.4.6.

2 Język ojczysty w edukacji szkolnej w Polsce, Czechach i na Stowacji. Red. E. Awramiuk, S. Štěpáník. Wydawnictwo Uniwersytetu w Białymstoku, Białystok 2020.

${ }^{3}$ Por. E. Kasperski: U podstaw komparatystyki. W: Komparatystyka dla humanistów. Red. M. Dąbrowski. Wydawnictwa Uniwersytetu Warszawskiego, Warszawa 2011, s. 17—86. 
w celach badawczych. Celem powstającej subdyscypliny, reprezentowanej przez badaczy publikujących $\mathrm{w}$ tomie, jest podejście poznawcze - ogarnięcie rodzimej, obcej i powszechnej rzeczywistości dydaktyki J1 jako wewnętrznie częściowo podobnej, ale też zróżnicowanej wspólnoty, powiązanej wieloma relacjami z innymi dyscyplinami. Wartością prezentowanych analiz jest więc możliwa wspólnota $\mathrm{J} 1$ - wyłaniająca się $\mathrm{z}$ różnic w wielojęzykowej koniunkcji, związkach, we wzajemnym oddziaływaniu i nakładaniu się na siebie oraz w przeplataniu i mieszaniu ze sobą.

Drugą wartością opracowania jest dedykowanie go przez autorów w całości funkcjonalnemu podejściu do nauczania języka ojczystego w szkole. Zarówno w typowych studiach lingwistycznych, jak i w dydaktyce języka ojczystego (także w glottodydaktyce) „funkcjonalność”, „funkcja” są rozumiane w określony sposób, nawiązują do funkcjonalizmu w językoznawstwie i do poglądów twórców kierunku na „strukturę języka i jego funkcję w interakcji społecznej"4. Po raz pierwszy pojęcie funkcji zostało użyte w stosunku do języka jako całości przez działającego w środowisku językoznawców Szkoły Praskiej Romana Jakobsona, który opisał sześć dziś dobrze znanych funkcji języka ${ }^{5}$. Badacze Szkoły pojmowali język jako system funkcjonalny, czyli jako system środków wyrazu służących do osiągania określonego celu. Poglądy tej grupy lingwistów przyczyniły się w znacznym stopniu do powstania i rozpowszechnienia semantycznej interpretacji funkcji - także w nauce języka. Za denotat/desygnat badacze uznawali na przykład zdarzenie opisywane w wypowiedzi, a oznaczenie konkretnej sytuacji lub czynności przez kategorię gramatyczną było interpretowane właśnie jako jej funkcja, uwzględniająca zarówno formy językowe, jak i oznaczaną przez formy pozatekstową rzeczywistość. Takie rozumienie funkcjonalności każe zwracać się $\mathrm{w}$ dydaktyce języka pierwszego/ojczystego ku łączeniu systematycznych funkcji elementów językowych (jak związki form będących wykładnikami kategorii gramatycznych) z oznaczaną przez nie rzeczywistością opisywaną w komunikacji; funkcja semantyczna — skierowana ku rzeczywistości pozatekstowej — powstaje bowiem wskutek współdziałania formy i kontekstu. Funkcja nie jest pojęciem abstrakcyjnym i nie istnieje w próżni. Przejawia się tylko w kontekście, który może mieć charakter leksykalny, ale przede wszystkim tekstowy, komunikacyjny, dyskursywny. Funkcjonalne nauczanie języka oznacza więc schemat jego przyswajania od funkcji do formy, co w praktyce

${ }^{4}$ M. Szymańska: Między nauka o języku a rozwijaniem języka. Wydawnictwo Naukowe Uniwersytetu Pedagogicznego, Kraków 2016, s. 119.

${ }^{5}$ Z kolei przez André Martineta została dobrze zarysowana funkcja komunikatywna, uważana przez niego za najważniejszą funkcję języka. Por. A. Martinet: Podstawy lingwistyki funkcjonalnej. [Wybór i przekł. L. Zawadowski]. Państwowe Wydawnictwo Naukowe, Warszawa 1970, s. $13-14$. 
szkolnej będzie prowadziło od użycia języka w komunikacji, do analizowania jego funkcji w wytworzonym tekście ${ }^{6}$.

Takie podejście do nauczania J1 charakteryzuje całą monografię: sześć rozbudowanych rozdziałów autorskich i współautorskich, poprzedzonych wstępem redaktorów tomu. Autorzy poszczególnych tekstów - uznani badacze: językoznawcy, dydaktycy języka, analitycy dyskursu edukacyjnego, reprezentujący kilka ośrodków naukowych z regionu Europy Środkowej: Uniwersytet Karola w Pradze (Jana Vlčková-Mejvaldová, Radka Holanová), Uniwersytet Palackiego w Ołomuńcu (Stanislav Štěpáník), Uniwersytet Pedagogiczny w Krakowie (Marta Szymańska), Uniwersytet w Białymstoku (Elżbieta Awramiuk, Małgorzata Frąckiewicz), Uniwersytet w Preszowie (Ludmila Liptáková, Eva Gogová, Martin Klimovič) — poszukują wspólnie modelowej ścieżki dla edukacji językowej.

Autorskie opracowania zostały wprowadzone redaktorskim uzasadnieniem potrzeby publikowania w tym dość młodym nurcie dydaktyki porównawczej języków ojczystych. Elżbieta Awramiuk i Stanislav Štepáník odwołują się we wstępie do publikacji stanowiących inspirację dla opracowania ${ }^{7}$, a także wskazują na źródło myśli komparatystycznej w zakresie nauczania/uczenia się języka ojczystego, czyli na działalność ARLE - The International Association for Research in L1 Education (languages, literatures and literacies), międzynarodowej społeczności poszukującej optymalnego sposobu edukacji w J1 (L1). Redaktorzy dostrzegają konieczność odpowiedzi na znane już z innych publikacji dydaktycznych wyzwania, przed którymi stoi współczesna edukacja J1, jak: edukalizacja, globalizacja, wielokulturowość, zmiany techniczno-kulturo-

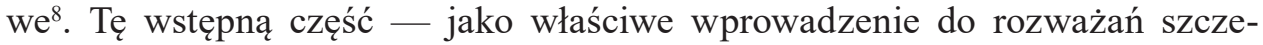
gółowych - opatrują obszerną literaturą na temat idei funkcjonalności w nauczaniu (funkcjonalnym) języka. Można żałować, że redaktorzy nie poszerzyli tego wstępnego rejestru o podstawową literaturę dotyczącą funkcjonalizmu również w teorii języka. Dla odbiorcy monografii (nauczyciela, studenta) taka bibliografia miałaby niewątpliwie dodatkowy walor poznawczy.

W Języku ojczystym w edukacji szkolnej... poruszono zagadnienia zróżnicowane, układają się one jednak w dość spójną całość — poszczególne rozdziały $\mathrm{i}$ tematy zespala bowiem ujęta $\mathrm{w}$ tytule koncepcja nauczania języka

${ }^{6}$ Por. M. Szymańska: Między nauką o języku a rozwijaniem języka..., s. 147.

7 Tworzą je prace szerszych zespołów, w których znaleźli się niektórzy autorzy monografii. Są to: Teaching of national languages in the V4 countries. Eds. M. Pieniążek, S. Štěpáník. Univerzita Karlova - Pedagogická fakulta, Praha 2016. Pobrano z: https://rep.up.krakow.pl/ xmlui/bitstream/handle/11716/1265/V4\%20monograph\%20elversion-20170216-123413389. pdf? sequence $=1 \&$ isAllowed=y [7.09.2021]; Vztah jazyka a komunikace $w$ cesko-slovensko-polske didakticke reflexi. Ed. S. Štěpáník. Univerzita Karlova — Pedagogická fakulta, Praha 2019.

${ }^{8}$ Zob. J. Nocoń: Lingwodydaktyka na progu XXI wieku. Koncepcje - konteksty - dylematy. Wydawnictwo Uniwersytetu Opolskiego, Opole 2018. 
rodzimego - nawiązująca, jak wspomniano, do idei funkcjonalnego (i komunikacyjnego) kształcenia językowego. Autorzy rozdziałów — badacze z Polski, Czech i ze Słowacji — prezentują w swych językach etnicznych problematykę z następujących obszarów dydaktyki języka ojczystego/pierwszego (J1):

1. Cele funkcjonalnego kształcenia językowego (czyli funkcjonalność w nauczaniu pomiędzy nauką języka a nauczaniem o języku ojczystym).

2. Pajdocentryczna orientacja w nauczaniu J1 (rozwijająca świadomość metajęzykową ucznia).

3. Zagadnienia z zakresu fonetyki w funkcjonalnym nauczaniu J1 (ukazane na podstawie materiału podręcznikowego).

4. Teorie komunikacyjno-stylistyczne i ich dydaktyczne implikacje w szkole.

5. Interdyscyplinarne uwarunkowania kompetencji tekstotwórczej młodszych uczniów.

6. Nazwy własne w systematycznym i okazjonalnym nauczaniu J1.

Już samo zestawienie zagadnień pokazuje, że badawczy ogląd rozmaitych aspektów nauczania języka różnicują perspektywa badawcza przyjmowana przez autorów opracowań w odniesieniu do analizowanych problemów, a także podstawa źródłowa. Przedmiotem dociekań są: sama koncepcja kształcenia językowego, podmiot nauczania i podejście dydaktyczne do niego, cele edukacji językowej, relacje pomiędzy treściami nauczania, pomocami dydaktycznymi (podręcznikami) i wymaganiami egzaminacyjnymi, a także relacje pomiędzy stanem wiedzy naukowej (między innymi językoznawczej) i jej przełożeniem na podręcznikowe polecenia dla ucznia, wreszcie - możliwości i braki w treściach programowych kształcenia językowego.

Mozaikę problemów podjętych w ujęciu porównawczym zakotwiczono w lingwodydaktyce, psychologii, pedagogice, naukach o edukacji, teorii komunikacji, stylistyce. Pragmatyczny charakter pierwszej dyscypliny sprawia, że badacze różnych subdyscyplin językoznawstwa i doświadczeni dydaktycy, eksponując w perspektywie edukacyjnej rolę różnych płaszczyzn języka w użyciu/komunikacji (płaszczyzny systemowej: fonetycznej, leksykalnej, gramatycznej; tekstowej: tekstotwórczej, stylistycznej), odsłaniają specyfikę funkcjonalnego podejścia do kształcenia języka ojczystego (macierzystego). Walory aplikacyjne poszczególnych części monografii stają się przy tym spoiwem dodatkowym, pozwalającym odczytywać całość jako efektywną, innowacyjną jedność, z założenia scalaną przyświecającą autorom ideą poznawania języka w sposób funkcjonalny, w procesie pełnej interakcji, z uwzględnieniem możliwości poznawczych i psychorozwojowych ucznia. Przyjęte założenia obligują bowiem badaczy do obudowania każdego rozdziału wnioskami dydaktycznymi lub propozycjami konkretnych rozwiązań edukacyjnych.

Całość rozważań została krótko podsumowana — należy żałować, że nie znalazły się w tym miejscu nieco szersze komparatystyczne wnioski. Zadbano 
za to o zróżnicowanych pod wzgledem narodowości odbiorców tomu - zaraz po wstępie przedstawiono sylwetki badaczy, autorów opracowań, ponadto wyposażono każdy rozdział w dwa streszczenia: wprowadzające w języku narodowym (w zespołach współautorskich $-\mathrm{w}$ języku jednego $\mathrm{z}$ autorów) oraz zamykające w języku angielskim.

\section{Funkcjonalność w nauczaniu języka ojczystego - przykłady rozwiązań}

Autorzy prezentowanych w książce zagadnień szczegółowych — niezależnie od rodzaju przedstawianych badań, a także zakresu i rezultatów poszukiwań - pamiętają o perspektywie nauki z „uczniem pośrodku”9 i biorą pod uwagę punkt widzenia odbiorcy działań dydaktycznych oraz jego możliwości.

Monografię otwiera rozdział autorstwa Marty Szymańskiej Na drodze do funkcjonalnego uczenia o języku na lekcjach języka ojczystego ${ }^{10}$. Autorka $\mathrm{w}$ tekście o charakterze teoretyczno-aplikacyjnym wprowadza w zagadnienie funkcjonalnego nauczania w kontekście edukacji polonistycznej. Nie można potrzeby nauczania/uczenia się zgodnej z podejściem funkcjonalnym i komunikacyjnym przedstawić jaśniej niż w prezentowanym opracowaniu. Badaczka w próbach odpowiedzi na pytania o cele nauczania języka w szkole i trwający od lat dysonans pomiędzy nauką języka a nauką o języku wskazuje, jak i kiedy uczynić wiedzę o języku ,wiedzą czynną, uświadomioną, nadbudowaną na proceduralnym fundamencie”, upotrzebnioną, jak i kiedy nauczyć „,przełączania wiedzy" z proceduralnej na deklaratywną:

Najważniejszy cel nauczania — rozwijanie języka ucznia — osiągany jest dzięki obserwacji i analizie testu, który rozumiany jest jako „całość myślowo-intencjonalna, ze swej natury podlegający regułom semantyczno-stylistycznym, nie zaś regułom strukturalnym" (Mrazek, 1997, s. 36). Tekst „pozyskiwany” jest dwukierunkowo: może on być efektem twórczo-

${ }^{9}$ We współczesnej, obowiązującej dziś koncepcji kształcenia języka ojczystego kładzie się szczególny nacisk na model edukacji „, z uczniem pośrodku”. W tym antropocentryczno-kulturowym nurcie wskazuje się na badanie nastawień i motywacji ucznia, jego predyspozycji, wyborów, zainteresowań i relacji międzyludzkich. Por. Z uczniem pośrodku. Podmiotowa dydaktyka literatury, języka, kultury. Red. Z. Budrewicz, M. Jędrychowska. Wydawnictwo Naukowe AP, Kraków 1999.

${ }_{10}$ M. Szymańska: Na drodze do funkcjonalnego uczenia o języku na lekcjach języka ojczystego. W: Język ojczysty w edukacji szkolnej..., s. 19-52. 
ści uczniów lub gotowym wzorem konkretnej wypowiedzi. W efekcie obserwacji, analizy, wykonania wypowiedź staje się „zauważalna, zamierzona, stosowna/niestosowna, jednym słowem — nieprzezroczysta" (Dyduch et al., 1994, s. 15) $)^{11}$.

Marta Szymańska ukazuje przy tym (na tle ujęć znanych i uznanych w tradycji polskiej myśli dydaktycznej) kolejne „kroki” budowania podejścia: holistyczne potraktowanie nauczania języka (między innymi stosowanie zasady stopniowania trudności), konieczne integrowanie różnych treści, wykorzystywanie kontekstu, doświadczeń ucznia (jego wiedzy proceduralnej), stosowanie „tekstocentryzmu” jako podstawy rozwoju języka uczniów. Tekst Szymańskiej to niezwykle cenna część monografii, otwierająca pole do dalszych rozważań i badań.

W kolejnym rozdziale, zatytułowanym Pedocentrická orientácia vyučovania materinského jazyka, dwie badaczki z Uniwersytetu w Preszowie, Ludmila Liptáková i Eva Gogová, już w tytule uznają za istotne przyznanie uczniowi centralnej pozycji w procesie nauczania języka ojczystego ${ }^{12}$. Autorskie podejście polega $\mathrm{w}$ tym przypadku na integrowaniu osiągnięć psycholingwistyki i psychodydaktyki w systemie teoretycznym przedmiotu, co oznacza w nauczaniu języka branie pod uwagę rzeczywistych potrzeb ucznia, a także jego rozwojowych umiejętności. Badaczki przedstawiają również edukacyjne implikacje badań, to znaczy na podstawie ustaleń dotyczących rozwoju i funkcji słowotwórstwa w mowie dziecka (jego wiedzy proceduralnej, niejawnej) ukazują możliwości rozwoju kompetencji słowotwórczych uczniów w młodszym wieku szkolnym. Szczególnie interesująca wydaje się propozycja wykorzystania umiejętności dzieci w zakresie tworzenia wyrazów do podniesienia uczniowskiej kompetencji rozumienia tekstów. Jak wykazują autorki, rośnie przy tym motywacja i pozytywne nastawienie ucznia do nauczania języka ojczystego (choć wywód przeprowadzono nie na przykładzie nauczania języka słowackiego, ale na materiale podręcznika biologii). Tekst słowackich autorek to przykład niezwykle rzetelnego opracowania badawczego, inspirującego do dalszych poszukiwań i opracowań dydaktycznych. Tym bardziej należy żałować, że opracowanie nie zyskało także polskiego punktu widzenia. Porównawcza prezentacja polskich badań z zakresu rozwoju języka dziecka (ze starszych badań na przykład prac Leona Kaczmarka, a z nowszych - Józefa Porayskiego-Pomsty i Barbary Bonieckiej) czy z psycholingwistyki (Barbary Bokus i Grażyny Krasowicz-Kupis), a także poszerzenie opracowania o polską propozycję dydaktyczną byłyby niezwykle cenne poznawczo.

11 Ibidem, s. 32.

12 L. Liptáková, E. Gogová: Pedocentrická orientácia vyučovania materinského jazyka. W: Język ojczysty w edukacji szkolnej..., s. 53-80. 
Problemy trudnej dydaktycznie, bo dotyczącej relacji pomiędzy mową a jej zapisem, płaszczyzny języka, odnoszonej przy tym do rozwijającego się językowo dziecka przedstawia rozdział autorstwa zespołu polsko-słowacko-czeskiego - Elżbiety Awramiuk, Ludmily Liptákovej i Jany Vlčkovej-Mejvaldovej. W tym w pełni komparatystycznym opracowaniu, pod tytułem Konwencje opisu wymowy w podręcznikach szkolnych do nauczania języka polskiego, czeskiego i słowackiego, zaprezentowane zostały konwencje opisu wymowy w wybranych polskich, czeskich i słowackich podręcznikach do języka ojczystego dla klas czwartej, piątej i szóstej szkoły podstawowej. Wyniki prekursorskiej pracy badaczek w budowaniu podstaw dydaktyki porównawczej prowadzą do niepokojących wniosków: sygnalizowanie formy dźwiękowej słów prowadzone jest niesystematycznie i niekonsekwentnie, a czasem z błędami:

Niespójność i brak systemowych rozwiązań w sygnalizacji formy dźwiękowej jednostek językowych postrzegamy jako najbardziej problematyczne zjawiska w analizowanych podręcznikach. Dominuje w nich zastosowanie reguł ortograficznych do zapisu formy dźwiękowej, co wspiera postrzeganie rzeczywistości dźwiękowej przez filtr reguł pisowni ${ }^{13}$.

Budujący jest za to fakt, że taka porównawcza analiza międzyjęzykowa może nie tylko ukazać podobieństwa w zaniedbaniach dydaktycznych, lecz także dać możliwość wspólnego tworzenia podstaw zmian w edukacji fonologicznej — ku efektywnemu budowaniu świadomości uczniów w tym zakresie.

Radka Holanová i Stanislav Štěpáník w opracowaniu Stylistika a didaktika: nové výzvy pro výuku mateřského jazyka poruszają zagadnienie odnoszące się do płaszczyzny tekstu — zajmują się szeroko ujętym problemem edukacji stylistyczno-komunikacyjnej, kształtowanej w czeskich szkołach nadal według reguł stylistyki opartej na paradygmacie strukturalistycznym ${ }^{14}$. W perspektywie współczesnej koncepcji stylistyki (za Janą Hoffmannovą - multidyscyplinarnej i interakcyjnej ${ }^{15}$ ) tradycyjne podejście wydaje się autorom przestarzałe - nie przynosi właściwych rezultatów w szkole, gdyż komunikat jest w nim traktowany jako twór statyczny, co jest w konflikcie nie tylko z aktualną wiedzą naukową, lecz także z celami dydaktycznymi. W tych ostatnich bowiem wyraźnie preferuje się dynamiczną koncepcję komunikacji, według

${ }^{13}$ E. Awramiuk, J. Vlčkova-Mejvaldova, L. Liptákova: Konwencje opisu wymowy w podręcznikach szkolnych do nauczania języka polskiego, czeskiego i słowackiego. W: Język ojczysty w edukacji szkolnej..., s. 101.

${ }^{14}$ R. Holanová, S. Štěpáník: Stylistika a didaktika: nové výzvy pro výuku mateřského jazyka. W: Język ojczysty w edukacji szkolnej ..., s. 110-151.

${ }_{15}$ Zob. J. Hoffmannová: Stylistika a ... Současná situace stylistiky. Trizonia, Praha 1997. 
której pełne kompetencje ma osoba, która elastycznie potrafiłaby dostosować styl swej wypowiedzi do sytuacji i intencji komunikacyjnych. Takie konstatacje na temat edukacji stylistycznej w szkole skłaniają autorów do podjęcia próby zbadania relacji pomiędzy trzema komponentami procesu kształcenia: zawartymi $\mathrm{w}$ podstawie programowej treściami nauczania, pomocami dydaktycznymi ( $\mathrm{w}$ artykule analizie poddano trzydzieści podręczników do szkół ponadgimnazjalnych) i wymaganiami egzaminacyjnymi do matury w zakresu stylistyki (i komunikacji). Autorzy po przeprowadzeniu analizy podręcznikowych charakterystyk stylów funkcjonalnych wskazują, że złożoność komunikacji jest w nich raczej lekceważona, a formy tekstowe przedstawiane są najczęściej jako abstrakcyjne modele oderwane od ich praktycznego zastosowania. Z opracowania płyną wnioski dla współczesnej szkoły (nie tylko w Czechach). Kształcenie języka pierwszego powinno:

— obejmować podczas pracy z tekstem pełne spektrum czynników komunikacyjnych;

- podążać za interaktywnością procesu komunikacji, to jest relacją między illokucją, lokucją i perlokucją.

Wywód dwojga autorów został zilustrowany przedstawieniem analiz w postaci czytelnych tabel, które wspierają proces odbioru (zwłaszcza analizy programu ramowego i wymagań egzaminacyjnych). Należy docenić szeroki zakres, jakość i rzetelność opracowania, można jedynie żałować, że w literaturze przedmiotu nie uwzględniono (poza Przewodnikiem po stylistyce polskiej) prac językoznawczych polskich badaczy stylu oraz zagadnień stylistyczno-genologicznych, jak choćby Marii Wojtak czy Stanisława Gajdy ${ }^{16}$, których publikacje wzmocniłyby komparatystyczny charakter rozdziału (w rozdziale przywołano natomiast polskie publikacje z lingwodydaktyki).

Autor kolejnego rozdziału, zatytułowanego Produkcia pisaných textov $v$ primárnom vzdelávaní na slovensku $v$ interdisciplinárnych súvislostiach: konfrontácia dvoch svetov, Martin Klimovič, ekspert zajmujący się narracją, poznawczymi aspektami tworzenia tekstu i dziecięcym twórczym pisaniem, poświęca rozważania procesowi pisania $\mathrm{w}$ szkole ${ }^{17}$. W opracowaniu konfrontuje dwa ,światy”: jeden jest wywiedziony ze współczesnej lingwistyki i szerzej - interdyscyplinarnej wiedzy na temat tworzenia tekstów, oparty na systematycznej obserwacji i opisie naturalnej, autentycznej komunikacji międzyludzkiej/dziecięcej oraz wiedzy na ten temat; drugi to sfera szkoły transformująca to zagadnienie bez dbałości o podstawowe warunki procesu

${ }^{16}$ Zob. np. M. Wojtak: Gatunki prasowe. Wydawnictwo Uniwersytetu Marii Curie-Skłodowskiej, Lublin 2004; S. Gajda: Podstawy badań stylistycznych nad językiem naukowym. Państwowe Wydawnictwo Naukowe, Warszawa 1982.

${ }_{17}$ M. Klimovič: Produkcia písaných textov v primárnom vzdelávaní na slovensku v interdisciplinárnych súvislostiach: konfrontácia dvoch svetov. W: Język ojczysty w edukacji szkolnej..., s. $152-181$. 
komunikacji w dyskursie szkolnym. Kontrast „światów” został ukazany na tle kwintesencji wiedzy naukowej o tworzeniu tekstów (autor czerpie ze stylistyki, z tekstologii, psycholingwistyki, teorii komunikacji, pragmatyki, językoznawstwa, psychologii komunikacji i pisania). Przedstawiono analizę dydaktyczną komponentu językowego i stylistycznego zadań oraz instrukcji tworzenia tekstu pisanego (narracyjnego, opisowego, informacyjnego) w podręcznikach języka słowackiego dla klas od drugiej do czwartej szkoły podstawowej. Część analityczna tekstu zwieńczona jest zestawieniem warunków tworzenia przekazów opisowych i informacyjnych, a także tezą nawiązującą do kognitywno-komunikacyjnej koncepcji rozwijania kompetencji tekstotwórczej uczniów. Pierwsza teza autora (do tworzonej koncepcji) brzmi: „Pisanie to sposób komunikacji. Celem produkcji/twórczości pisemnej jest wyrażenie myśli, skierowanie jej do odbiorcy"18. Zastanawiam się, czy biorąc pod uwagę kognitywno-komunikacyjne uczenie się/kształcenia języka pierwszego, nie rozszerzyć tej formuły do twierdzenia: Pisanie w procesie komunikacji to komunikat zwrotny uruchamiany w sprzężeniu zwrotnym przez komunikat inspirujący nadawcy nauczyciela (autora zadania w podręczniku) ${ }^{19}$. Wypowiedź pisemna ucznia byłaby wtedy traktowana jako komunikat, który pojawia się w charakterze odpowiedzi — jako ogniwo w całym łańcuchu komunikatów (kolejnym będzie odpowiedź nauczyciela w postaci recenzji pracy). Podczas komunikacji pisanej w dyskursie edukacyjnym należałoby także pamiętać, że sytuacja komunikacyjna piszącego ucznia (jak wynika z moich badań) jest skomplikowana, gdyż jego komunikaty w postaci tekstu mają dwóch adresatów: wewnętrznego (zawartego w komunikacie uruchamiającym wypowiedź) oraz zewnętrznego nauczyciela. Niezależnie bowiem od stopnia naturalizacji sytuacji nadawania, sygnalizowanej uczniowi, ma on świadomość istnienia rzeczywistego odbiorcy tekstu i swój tekst kształtuje również ze względu na niego.

Recenzenckie rozważania w żaden sposób nie umniejszają wartości opracowania Martina Klimoviča, są jedynie dowodem, że tekst uruchamia wiele dodatkowych wątków badawczych, które zasługują w przyszłości na opracowanie. Zastosowanie w nauce J1 proponowanych przez autora trzech zasad poznawczo-komunikacyjnego podejścia do nauczania pisania może się przyczynić do wzorowego budowania kompetencji tekstotwórczej uczniów.

Udane „domknięcie” prezentowanej koncepcji funkcjonalnego uczenia języka ojczystego stanowi rozdział autorstwa Małgorzaty Frąckiewicz pod

${ }^{18}$ Ibidem, s. 164, tłum. - B.S.N.

19 Por. D. Bula, B. Niesporek-Szamburska: Kontakt językowy nauczyciel - uczeń (na podstawie recenzji). W: Kłopotliwy problem - badanie polonistycznych osiagnięć uczniów. Red. H. Kosętka, Z. Uryga. Wydawnictwo Akademii Pedagogicznej, Kraków 2001, s. 153-166;

D. Bula, B. Niesporek-Szamburska: Próba dialogu nauczyciela z uczniem na przykładzie recenzji prac uczniowskich oraz opisów osiagnięć dzieci. W: Język w przestrzeni edukacyjnej. Red. R. Mrózek. Wydawnictwo Uniwersytetu Śląskiego, Katowice 2000, s. 123-128. 
tytułem Walory poznawcze nazw własnych $w$ systemowym $i$ okazjonalnym nauczaniu języka polskiego ${ }^{20}$. Autorka wskazuje bowiem na upotrzebnienie wiedzy językowej (tu: onomastycznej, ale podobne funkcje może pełnić na przykład wiedza historycznojęzykowa) ,przy okazji”, gdy kontekst sytuacyjny (rzeczywisty i literacki) sam uruchamia możliwości atrakcyjnego poznawczo i praktycznie kształcenia językowego. Onomastyka ma wiele walorów, niejako prowokuje do sięgania w głąb lingwistycznej domeny, a to umożliwia wypełnianie luki w świadomości językowej — takiej budowanej co dnia, otwieranej przez miejsce i czas, w każdym aspekcie. Autorce udało się wszystkie te walory w sposób profesjonalny pokazać. Liczne propozycje dydaktyczne umieszczone na końcu rozdziału stanowią dodatkowy, aplikacyjny wymiar tekstu.

\section{Podsumowanie}

Jak wynika z uwag odnoszących się do publikacji jako całości oraz poszczególnych jej części, monografia Język ojczysty w edukacji szkolnej w Polsce, Czechach i na Stowacji stanowi unikalny wkład w budującą się dydaktykę porównawczą J1 i poszerza niewielki jeszcze dorobek lingwodydaktyki porównawczej. Wzbogaca także stan badań wyznaczonych przez temat rozważań, którym stało się w prezentowanym tomie nauczanie funkcjonalne języka ojczystego widziane w ujęciu komunikacyjnym. Wymowa całości ,podświetla z bazy" dokumenty oświatowe i prezentowane w podręcznikach treści, kieruje czytelnika ku ich wnikliwemu czytaniu i porównywaniu, pozwala również w sposób wyważony podchodzić do działań edukacyjnych. Opracowanie umożliwia także poznanie wzorców i możliwości współczesnego warsztatu badawczego językoznawcy dydaktyka, prezentuje konkretne rozwiązania dydaktyczne i wzbogaca wiedzę nauczyciela języka ojczystego oraz adepta zawodu na temat nowoczesnego, holistycznego i skutecznego nauczania języka z pełną dbałością o ucznia.

Uważna analiza zawartości tej wielojęzycznej monografii — wysoka jakość wszystkich prezentowanych w tomie rozdziałów, zarówno przedstawionych analiz, jak i wniosków oraz propozycji dydaktycznych profilujących rozumienie i wykorzystanie w praktyce funkcjonalnego podejścia do nauczania/ uczenia się J1 — języka ojczystego (mateřského/materinského) — pozwala uznać tę publikację za potrzebną w szerokim, międzynarodowym odbiorze,

20 M. Frąckiewicz: Walory poznawcze nazw własnych $w$ systemowym i okazjonalnym nauczaniu języka polskiego. W: Język ojczysty w edukacji szkolnej..., s. 182-209. 
nie tylko akademickim. A podobieństwo języków słowiańskich i wzajemne ich rozumienie w grupie Słowian stwarza szansę na zaistnienie publikacji wśród językoznawców i dydaktyków w regionie Europy Środkowej.

\section{Bibliografia}

Awramiuk E., Vlčkova-Mejvaldova J., Liptákova L.: Konwencje opisu wymowy w podręcznikach szkolnych do nauczania języka polskiego, czeskiego i słowackiego. W: Język ojczysty w edukacji szkolnej w Polsce, Czechach i na Słowacji. Red. S. Štěpáník, E. Awramiuk. Wydawnictwo Uniwersytetu w Białymstoku, Białystok 2020, s. 81-109.

Bula D., Niesporek-Szamburska B.: Kontakt językowy nauczyciel - uczeń (na podstawie recenzji). W: Kłopotliwy problem - badanie polonistycznych osiagnięć uczniów. Red. H. Kosętka, Z. Uryga. Wydawnictwo Akademii Pedagogicznej, Kraków 2001, s. 153-166.

Bula D., Niesporek-Szamburska B.: Próba dialogu nauczyciela z uczniem na przykładzie recenzji prac uczniowskich oraz opisów osiagnięć dzieci. W: Język w przestrzeni edukacyjnej. Red. R. Mrózek. Wydawnictwo Uniwersytetu Śląskiego, Katowice 2000, s. 123-128.

Frąckiewicz M.: Walory poznawcze nazw własnych w systemowym i okazjonalnym nauczaniu języka polskiego w Polsce, Czechach i na Słowacji. W: Język ojczysty w edukacji szkolnej w Polsce, Czechach i na Słowacji. Red. S. Štěpáník, E. Awramiuk. Wydawnictwo Uniwersytetu w Białymstoku, Białystok 2020, s. 182-209.

Gajda S.: Podstawy badań stylistycznych nad językiem naukowym. Państwowe Wydawnictwo Naukowe, Warszawa 1982.

Hoffmannová J.: Stylistika a ... Současná situace stylistiky. Trizonia, Praha 1997.

Holanová R., Štěpáník S.: Stylistika a didaktika: nové výzvy pro výuku mateřského jazyka. W: Język ojczysty w edukacji szkolnej w Polsce, Czechach i na Słowacji. Red. S. Štěpáník, E. Awramiuk. Wydawnictwo Uniwersytetu w Białymstoku, Białystok 2020, s. 110-151.

Kasperski E.: U podstaw komparatystyki. W: Komparatystyka dla humanistów. Red. M. Dąbrowski. Wydawnictwa Uniwersytetu Warszawskiego, Warszawa 2011, s. 17-86.

Klimovič M.: Produkcia písaných textov v primárnom vzdelávani na slovensku v interdisciplinárnych súvislostiach: konfrontácia dvoch svetov. W: Język ojczysty w edukacji szkolnej w Polsce, Czechach i na Słowacji. Red. S. Štěpáník, E. Awramiuk. Wydawnictwo Uniwersytetu w Białymstoku, Białystok 2020, s. 152-181.

Liptáková L., Gogová E.: Pedocentrická orientácia vyučovania materinského jazyka. W: Język ojczysty w edukacji szkolnej w Polsce, Czechach i na Słowacji. Red. S. Štěpáník, E. Awramiuk. Wydawnictwo Uniwersytetu w Białymstoku, Białystok 2020, s. 53-80.

Martinet A.: Podstawy lingwistyki funkcjonalnej. [Wybór i przekł. L. Zawadowski]. Państwowe Wydawnictwo Naukowe, Warszawa 1970.

Nocoń J.: Lingwodydaktyka na progu XXI wieku. Koncepcje - konteksty — dylematy. Wydawnictwo Uniwersytetu Opolskiego, Opole 2018.

Pieniążek M.: Język ojczysty jako ,, software”. Polityka językowa i technologia. „LIK: časopis za literaturu i kulturu" 2017, vol. 3, no. 4, s. 153-164. https://doi.org/10.18485/ai_lik.2017.3.4.6.

Szymańska M.: Między nauką o języku a rozwijaniem języka. Wydawnictwo Naukowe Uniwersytetu Pedagogicznego, Kraków 2016. 
Szymańska M.: Na drodze do funkcjonalnego uczenia o języku na lekcjach języka ojczystego. W: Język ojczysty w edukacji szkolnej w Polsce, Czechach i na Stowacji. Red. E. Awramiuk, S. Štěpáník. Wydawnictwo Uniwersytetu w Białymstoku, Białystok 2020, s. 19-52.

Teaching of national languages in the V4 countries. Eds. M. Pieniążek, S. Štěpáník. Univerzita Karlova - Pedagogická fakulta, Praha 2016. Pobrano z: https://rep.up.krakow.pl/xmlui/bitstream/handle/11716/1265/V4\%20monograph\%20elversion-20170216-123413389. pdf? sequence=1\&isAllowed=y [7.09.2021].

Vztah jazyka a komunikace w cesko-slovensko-polske didakticke reflexi. Ed. S. Štěpáník. Univerzita Karlova - Pedagogická fakulta, Praha 2019.

Wojtak M.: Gatunki prasowe. Wydawnictwo Uniwersytetu Marii Curie-Skłodowskiej, Lublin 2004. Z uczniem pośrodku. Podmiotowa dydaktyka literatury, języka, kultury. Red. Z. Budrewicz, M. Jędrychowska. Wydawnictwo Naukowe AP, Kraków 1999. 